\title{
Respon tanaman Kedelai terhadap pemupukan kombinasi bio-slurry dengan urea
}

\author{
(Response of soybean plants affected by combination bio-slurry with urea fertilization) \\ R. M. Indrawan, Y. Yafizham, S. Sutarno \\ Agroecotechnology, Faculty of Animal and Agricultural Sciences, Diponegoro University \\ Tembalang Campus, Semarang 50275 - Indonesia \\ Corresponding E-mail : rezamindrawan@gmail.com
}

\begin{abstract}
The research aimed to study the effect of combination fertilizer by bio-slurry and urea on the growth and yield of soybean. The experiment was assigned in monofactor randomized complete block design with treatment P0 (Control, without fertilizer), P1 (Bio-slurry $10 \mathrm{t} / \mathrm{ha}+$ Urea $25 \mathrm{~kg} / \mathrm{ha}$ ), P2 (Bioslurry $10 \mathrm{t} / \mathrm{ha}+$ Urea $50 \mathrm{~kg} / \mathrm{ha}$ ), P3 (Bio-slurry $10 \mathrm{t} / \mathrm{ha}+$ Urea $75 \mathrm{~kg} / \mathrm{ha}$ ), P4 (Bio-slurry $10 \mathrm{t} / \mathrm{ha}+$ Urea $100 \mathrm{~kg} / \mathrm{ha}$ ), P5 (Bio-slurry $10 \mathrm{t} / \mathrm{ha}$ ). Each treatment was replicated five times. Parameters measured were plant height, leaf number, plant dry matter, 100 seeds weight, and nitrogen total of soybean's stover. Data were subjected to anova and followed by DMRT. The result showed that combination by bioslurry with urea has incrased growth and yield of soybean significantly $(\mathrm{P}<0,05)$. Bio-slurry + urea $50 \mathrm{~kg} / \mathrm{ha}$ has increased high plant $(28.10 \mathrm{~cm})$ and leave number $(8.48$ leaves $)$ higher compared to another treatments. Bio-slurry + urea $25 \mathrm{~kg} / \mathrm{ha}$ non-significantly different with bio-slurry + urea $50 \mathrm{~kg} / \mathrm{ha}$ on dry matter and 100 seeds weight, although higher than another treatments. Nitrogen total of stover of $62.88 \mathrm{~g} / \mathrm{plant}$ has resulted by bio-slurry + urea $25 \mathrm{~kg} / \mathrm{ha}$ which was higher than other treatments, but non-significantly different with bio-slurry + urea $50 \mathrm{~kg} / \mathrm{ha}(50.63 \mathrm{~g} /$ plant $)$.
\end{abstract}

Keyword : Bio-slurry, combination, growth, soybean, urea, yield

\begin{abstract}
ABSTRAK
Penelitian bertujuan untuk mengkaji pengaruh pemupukan kombinasi bio-slurry dengan urea terhadap pertumbuhan dan produksi kedelai. Penelitian menggunakan rancangan acak kelompok dengan perlakuan P0 (Kontrol, tanpa pupuk), P1 (Bio-slurry 10 ton/ha + Urea $25 \mathrm{~kg} / \mathrm{ha}$ ), P2 (Bio-slurry 10 ton/ha + Urea $50 \mathrm{~kg} / \mathrm{ha}$ ), P3 (Bio-slurry 10 ton/ha + Urea $75 \mathrm{~kg} / \mathrm{ha}$ ), P4 (Bio-slurry 10 ton/ha + Urea $100 \mathrm{~kg} / \mathrm{ha}$ ), P5 (Bio-slurry 10 ton/ha), diulang sebanyak 5 kali. Parameter yang diamati tinggi tanaman, jumlah daun, bahan kering tanaman, bobot 100 biji, dan produksi nitrogen jerami kedelai. Data di analisis ragam dan uji lanjut dengan Duncan's Multiple Range Test (DMRT). Hasil penelitian menunjukkan bahwa perlakuan bio-slurry + urea $50 \mathrm{~kg} / \mathrm{ha}$ menghasilkan tinggi tanaman kedelai $28,10 \mathrm{~cm}$ dan jumlah daun kedelai 8,48 helai nyata lebih tinggi dibanding perlakuan lainnya. Perlakuan bio-slurry + urea $25 \mathrm{~kg} / \mathrm{ha}$ menghasilkan bahan kering dan bobot 100 biji kedelai tidak berbeda nyata terhadap perlakuan bio-slurry + urea $50 \mathrm{~kg} / \mathrm{ha}$ tetapi nyata lebih tinggi dibanding lainnya. Perlakuan bio-slurry + urea $25 \mathrm{~kg} / \mathrm{ha}$ menghasilkan produksi $\mathrm{N}$ jerami $62,88 \mathrm{~g} /$ tanaman nyata lebih tinggi dibanding perlakuan lainnya tetapi tidak berbeda nyata terhadap perlakuan bio-slurry + urea $50 \mathrm{~kg} / \mathrm{ha}$ yaitu $50,63 \mathrm{~g} /$ tanaman.
\end{abstract}

Kata kunci : Bio-slurry, kedelai, kombinasi, pertumbuhan, produksi tanaman, urea

\section{PENDAHULUAN}

Kedelai merupakan tanaman pangan semusim yang telah banyak dibudidayakan di
Indonesia setelah padi dan jagung. Kedelai merupakan sumber protein nabati utama yang paling diminati oleh masyarakat. Protein nabati masih menjadi pilihan masyarakat karena 
memiliki harga yang lebih murah dibanding sumber protein lainnya sehingga terjangkau oleh seluruh lapisan masyarakat (Mukhoyaroh, 2015). Kedelai mengandung protein nabati sekitar 18$22 \%$ yang terdiri atas $85 \%$ lemak tidak jenuh. Kebutuhan kedelai semakin meningkat, mengingat jumlah penduduk Indonesia dari tahun ke tahun bertambah banyak. Produksi kedelai pada tahun 2015 sebesar 963.183 ton (BPS, 2016). Kementerian pertanian merencanakan pencapaian produksi kedelai tahun 2016 - 2019 berturut-turut sebesar 1.200 .000 ton, 1.817 .000 ton, 2.941 .000 ton, 3.000.000 ton (Kementerian Pertanian, 2015).

Peningkatan produksi kedelai harus dilakukan untuk memenuhi kebutuhan kedelai di pasaran. Salah satu cara peningkatan produksi kedelai adalah dengan perbaikan sistem tanam dan pemupukan berimbang. Pemupukan berimbang antara urea yang dikombinasikan dengan pupuk organik dapat dijadikan salah satu upaya untuk meningkatkan pertumbuhan dan produksi kedelai. Pupuk organik memiliki fungsi kimia yang berperan penting dalam penyediaan hara makro dan mikro meskipun jumlahnya relatif sedikit (Suriadikarta et al., 2006). Pemberian pupuk organik ke dalam tanah dapat memperbaiki sifat fisik, kimia, dan biologi tanah, menyuburkan tanah, menambah unsur hara tanah, dan meningkatkan kapasitas mengikat air tanah (Satwiko et al., 2013). Pupuk organik yang diberikan pada tanaman kedelai dapat memperbaiki pertumbuhan akar, batang, dan daun (Ghulmahdi dan Nuraeni, 2009).

Bio-slurry merupakan produk akhir pengolahan limbah yang berbentuk lumpur yang sangat bermanfaat sebagai sumber nutrisi untuk tanaman. Bio-slurry padat memiliki kandungan unsur hara makro $\mathrm{N}: 2,05 \%, \mathrm{P}_{2} \mathrm{O}_{5}: 2,70 \%, \mathrm{~K}_{2} \mathrm{O}$ : $0,58 \%$. Keunggulan bio-slurry antara lain dapat dapat menambahkan humus sebanyak 10-12\%, mendukung aktivitas perkembangan cacing dan mikroba yang bermanfaat bagi tanaman, bioslurry bebas dari bakteri pembawa penyakit pada tanaman, dikarenakan pada saat proses fermentasi di reaktor biogas dapat membunuh organisme yang menyebabkan penyakit pada tanaman (Tim Biogas Rumah, 2013). Pupuk organik belum dapat memenuhi kebutuhan unsur hara tanaman kedelai secara optimal, penambahan pupuk anorganik diperlukan untuk menunjang kebutuhan hara tanaman kedelai (Elizabeth, 2014). Urea mengandung unsur nitrogen yang berfungsi untuk merangsang pertumbuhan secara keseluruhan, khususnya batang, cabang, dan daun. Berperan dalam pembentukan hijau daun untuk menunjang proses fotosintesis. Membentuk protein, lemak, dan berbagai persenyawaan organik lainnya. Jika tanaman kekurangan unsur nitrogen maka tanaman akan tumbuh kurus, daun menjadi kuning. Selanjutnya, daun mengering dari bagian bawah menuju bagian atas. Buah tanaman akan tumbuh kerdil kekuningan dan cepat matang (Lingga dan Marsono, 2013).

Penelitian bertujuan untuk mengkaji pengaruh pemupukan kombinasi bio-slurry dengan urea terhadap pertumbuhan dan produksi tanaman kedelai.

\section{MATERI DAN METODE}

\section{Materi}

Penelitian telah dilaksanakan pada tanggal 21 Juli - 30 November 2016 di Lahan Percobaan Fakultas Peternakan dan Pertanian, Universitas Diponegoro. Analisis lanjutan di Laboratorium Ekologi dan Produksi Tanaman, Fakultas Peternakan dan Pertanian, Universitas Diponegoro, Semarang. Bahan yang digunakan benih kedelai varietas grobogan, pestisida, pupuk bio-slurry padat, urea, SP-36 dan $\mathrm{KCl}$.

\section{Metode}

Penelitian dilakukan dengan pembuatan petak percobaan dengan ukuran $4 \times 2 \mathrm{~m}^{2}$ sejumlah 30 petak. Kemudian dilakukan analisis nutrisi pupuk bio-slurry dan kimia tanah awal. Kedelai ditanam secara jajar legowo $3: 1$ dengan jarak penanaman $25 \mathrm{~cm}$ dari tepi, berikutnya 3 baris kedelai dengan jarak tanam antar baris kedelai 25 $\mathrm{cm}$. Kemudian $50 \mathrm{~cm}$ selanjutnya legowo tanpa penanaman dan seterusnya hingga petak terpenuhi tanaman. Jarak tanam yang digunakan $25 \mathrm{x} 25 \mathrm{~cm}$.

Pemupukan dilakukan dengan cara spot placement sesuai dosis perlakuan. Pemupukan bio-slurry dilakukan pada saat pengolahan tanah. Pemupukan tambahan berupa SP-36 $100 \mathrm{~kg} / \mathrm{ha}$ dan $\mathrm{KCl} 50 \mathrm{~kg} / \mathrm{ha}$. Pemupukan urea dan $\mathrm{KCl}$ dilakukan dua kali yaitu pada 7 hari setelah tanam 
dan 35 hari setelah tanam dengan dosis masingmasing setengah bagian. Pemupukan SP-36 dilakukan pada saat tanaman berumur 7 hari setelah tanam.

Pemeliharaan tanaman meliputi penyiraman, penjarangan, penyulaman, penyiangan dan pengendalian organisme pengganggu tanaman menggunakan pestisida kimia. Tanaman kedelai dipanen pada saat masak fisiologis dengan tanda polong berwarna kuning kecoklatan dan daunnya mulai menguning ( $75 \%$ dari populasi).

Parameter yang diamati tinggi tanaman, jumlah daun, bahan kering tanaman, bobot 100 biji, dan produksi nitrogen jerami kedelai.

\section{Rancangan Penelitian dan Analisis Data}

Rancangan yang digunakan adalah Rancangan Acak Kelompok monofaktor. Perlakuan yang diberikan adalah kombinasi pupuk organik dengan urea yaitu P0. Kontrol (tanpa pupuk), P1. Bio-slurry 10 ton/ha + Urea $25 \mathrm{~kg} / \mathrm{ha}$, P2. Bio-slurry 10 ton $/ \mathrm{ha}+$ Urea $50 \mathrm{~kg} / \mathrm{ha}, \mathrm{P} 3$. Bioslurry 10 ton/ha + Urea $75 \mathrm{~kg} / \mathrm{ha}, \mathrm{P} 4$. Bio-slurry 10 ton/ha + Urea $100 \mathrm{~kg} / \mathrm{ha}$. P5. Bio-slurry 10 ton/ha. Data dianalisis ragam dan uji Duncan's Multiple Range Test (DMRT) pada taraf $\alpha=5 \%$.

\section{HASIL DAN PEMBAHASAN}

\section{Pertumbuhan Tanaman Kedelai}

Hasil analisis ragam menunjukkan bahwa perlakuan pemupukan kombinasi bio-slurry dengan urea berpengaruh nyata $(\mathrm{P}<0,05)$ terhadap tinggi tanaman dan jumlah daun. Hasil uji DMRT perlakuan pemupukan kombinasi bio-slurry dengan urea terhadap pertumbuhan tanaman kedelai tercantum pada Tabel 1.

Berdasarkan hasil uji DMRT menunjukkan bahwa perlakuan bio-slurry 10 ton/ha + urea 50 $\mathrm{kg} / \mathrm{ha}(\mathrm{P} 2)$ menghasilkan tinggi tanaman $28,10 \mathrm{~cm}$ nyata lebih tinggi $(\mathrm{P}<0,05)$ dibanding perlakuan lainnya. Perlakuan bio-slurry 10 ton/ha + urea 100 $\mathrm{kg} / \mathrm{ha}$ (P4) tidak berbeda nyata terhadap perlakuan bio-slurry 10 ton/ha (P5) masing-masing 24,21 cm dan $24,16 \mathrm{~cm}$. Perlakuan tanpa pupuk (kontrol) 0 $\mathrm{kg} / \mathrm{ha}$ (P0) menghasilkan tinggi tanaman $17,93 \mathrm{~cm}$ nyata lebih rendah $(\mathrm{P}<0,05)$ dibanding perlakuan lainnya.

Kombinasi bio-slurry dengan urea $50 \mathrm{~kg} / \mathrm{ha}$ mampu menyediakan nitrogen yang optimal bagi pertumbuhan tanaman kedelai. Nitrogen $(\mathrm{N})$ menjadi salah satu faktor pembatas pertumbuhan tanaman. Kekurangan $\mathrm{N}$ menyebabkan tanaman tumbuh kerdil, daun menguning dan gagal panen, sedangkan kelebihan $\mathrm{N}$ dapat menyebabkan ketidakseimbangan unsur hara sehingga pertumbuhan tanaman terganggu (Lingga dan Marsono, 2013). Pada saat fase vegetatif tanaman, jaringan meristem yang akan melakukan pembelahan, perpanjangan, dan pembesaran sel membutuhkan nitrogen yang cukup untuk pembentukan dinding sel dan protoplasma (Made, 2010).

Berdasarkan hasil uji DMRT menunjukkan bahwa perlakuan bio-slurry 10 ton/ha + urea 50 $\mathrm{kg} / \mathrm{ha}(\mathrm{P} 2)$ menghasilkan jumlah daun 8,48 nyata lebih tinggi $(\mathrm{P}<0,05)$ dibanding perlakuan lainnya. Perlakuan bio-slurry 10 ton/ha + urea $25 \mathrm{~kg} / \mathrm{ha}$ (P1) tidak berbeda nyata terhadap perlakuan bioslurry $10 \mathrm{ton} / \mathrm{ha}+$ urea $75 \mathrm{~kg} / \mathrm{ha}(\mathrm{P} 3)$ masingmasing 7,56 dan 7,41. Perlakuan tanpa pupuk (kontrol) $0 \mathrm{~kg} / \mathrm{ha}(\mathrm{P} 0)$ menghasilkan jumlah daun

Tabel 1. Rerata Tinggi Tanaman dan Jumlah Daun pada Kombinasi Pemupukan Bio-slurry dengan Urea

\begin{tabular}{|c|c|c|}
\hline Perlakuan & Tinggi Tanaman & Jumlah daun \\
\hline & .... & ..helai. \\
\hline $\mathrm{P}_{0}$. Tanpa Pupuk (kontrol) $0 \mathrm{~kg} / \mathrm{ha}$ & $17,93^{\mathrm{e}}$ & $5,06^{\mathrm{e}}$ \\
\hline $\mathrm{P}_{1}$. Bioslurry 10 ton $/ \mathrm{ha}+$ Urea $25 \mathrm{~kg} / \mathrm{ha}$ & $26,54^{\mathrm{b}}$ & $7,56^{\mathrm{b}}$ \\
\hline $\mathrm{P}_{2 .}$ Bioslurry 10 ton $/ \mathrm{ha}+$ Urea $50 \mathrm{~kg} / \mathrm{ha}$ & $28,10^{\mathrm{a}}$ & $8,48^{\mathrm{a}}$ \\
\hline $\mathrm{P}_{3}$. Bioslurry 10 ton/ha + Urea $75 \mathrm{~kg} / \mathrm{ha}$ & $25,08^{\mathrm{c}}$ & $7,41^{\mathrm{b}}$ \\
\hline $\mathrm{P}_{4}$. Bioslurry 10 ton/ha + Urea $100 \mathrm{~kg} / \mathrm{ha}$ & $24,21^{\mathrm{d}}$ & $6,82^{\mathrm{c}}$ \\
\hline $\mathrm{P}_{5 .}$ Bioslurry 10 ton $/ \mathrm{ha}$ & $24,16^{\mathrm{d}}$ & $5,99^{\mathrm{d}}$ \\
\hline
\end{tabular}

Keterangan : superskrip berbeda pada kolom yang sama menunjukkan perbedaan nyata $(\mathrm{P}<0,05)$ 
5,06 nyata lebih rendah $(\mathrm{P}<0,05)$ dibanding perlakuan lainnya.

Perlakuan bio-slurry dengan urea $50 \mathrm{~kg} / \mathrm{ha}$ mampu menghasilkan jumlah daun nyata lebih tinggi dibanding lainnya karena pemupukan berimbang pada dosis yang tepat mampu meningkatkan jumlah daun. Unsur $\mathrm{N}$ berfungsi untuk merangsang pertumbuhan tanaman secara keseluruhan, terutama pembentukan batang, cabang dan daun (Lingga dan Marsono, 2013). Pemenuhan kebutuhan $\mathrm{N}$ pada tanaman akan menyebabkan terjadinya keseimbangan rasio antara akar dan daun, sehingga pertumbuhan vegetatif akan berjalan sempurna (Made, 2010). Jika pasokan unsur $\mathrm{N}$ pada tanaman terpenuhi maka daun tanaman akan tumbuh besar dan memperluas permukaan untuk proses fotosintesis (Fahmi et al, 2010).

\section{Produksi Bahan Kering dan Bobot 100 Biji Kedelai}

Hasil analisis ragam menunjukkan bahwa perlakuan pemupukan kombinasi bio-slurry dengan urea berpengaruh nyata $(\mathrm{P}<0,05)$ terhadap bahan kering dan bobot 100 biji. Hasil uji DMRT perlakuan lainnya tetapi tidak berbeda nyata terhadap perlakuan bio-slurry 10 ton/ha + urea 50 $\mathrm{kg} / \mathrm{ha}(\mathrm{P} 2)$ yaitu $19,08 \mathrm{~g}$. Perlakuan tanpa pupuk (kontrol) $0 \mathrm{~kg} / \mathrm{ha}(\mathrm{P} 0)$ menghasilkan bahan kering tanaman $7,75 \mathrm{~g}$ nyata lebih rendah $(\mathrm{P}<0,05)$ dibanding perlakuan lainnya.

Perlakuan bio-slurry dengan urea $25 \mathrm{~kg} / \mathrm{ha}$ mampu menghasilkan bahan kering tanaman nyata lebih tinggi dibanding lainnya. Salah satu faktor yang mempengaruhi bahan kering tanaman adalah ketersediaan unsur hara. Pemberian pupuk limbah biogas dan pupuk NPK mampu meningkatkan bahan kering tanaman kedelai (Ramalia, 2015). Pasokan $\mathrm{N}$ berlebih akan menyebabkan pembentukan protoplasma yang tinggi, sehingga tanaman banyak mengandung air (Munawar, 2011). Semakin tinggi kadar air pada tanaman maka bahan kering tanaman semakin rendah.

Berdasarkan hasil uji DMRT menunjukkan bahwa perlakuan bio-slurry 10 ton/ha + urea 25 $\mathrm{kg} / \mathrm{ha}$ (P1) menghasilkan bobot 100 biji 20 g nyata lebih tinggi $(\mathrm{P}<0,05)$ dibanding perlakuan lainnya tetapi tidak berbeda nyata terhadap perlakuan bioslurry $10 \mathrm{ton} / \mathrm{ha}+$ urea $50 \mathrm{~kg} / \mathrm{ha}(\mathrm{P} 2)$ yaitu $19 \mathrm{~g}$. Perlakuan tanpa pupuk (kontrol) $0 \mathrm{~kg} / \mathrm{ha}$ (P0) menghasilkan bobot 100 biji $12 \mathrm{~g}$ nyata lebih

Tabel 2. Rerata Bahan Kering Tanaman dan Bobot 100 Biji pada Kombinasi Pemupukan Bio-slurry dengan Urea.

\begin{tabular}{|c|c|c|}
\hline Perlakuan & $\begin{array}{c}\text { Bahan Kering } \\
\text { Tanaman } \\
\end{array}$ & Bobot 100 Biji \\
\hline & $\frac{1}{\ldots . g \ldots \ldots \ldots \ldots}$ & $\ldots \ldots \ldots \ldots . . . \ldots \ldots \ldots$ \\
\hline $\mathrm{P}_{0}$. Tanpa Pupuk (kontrol) $0 \mathrm{~kg} / \mathrm{ha}$ & $7,75^{\mathrm{e}}$ & $12,0^{\mathrm{e}}$ \\
\hline $\mathrm{P}_{1}$. Bioslurry 10 ton $/ \mathrm{ha}+$ Urea $25 \mathrm{~kg} / \mathrm{ha}$ & $22,33^{\mathrm{a}}$ & $20,0^{\mathrm{a}}$ \\
\hline $\mathrm{P}_{2}$. Bioslurry 10 ton $/ \mathrm{ha}+$ Urea $50 \mathrm{~kg} / \mathrm{ha}$ & $19,08^{\mathrm{ab}}$ & $19,0^{\mathrm{ab}}$ \\
\hline $\mathrm{P}_{3}$. Bioslurry 10 ton $/ \mathrm{ha}+$ Urea $75 \mathrm{~kg} / \mathrm{ha}$ & $15,15^{\mathrm{bc}}$ & $18,2^{\mathrm{bc}}$ \\
\hline $\mathrm{P}_{4}$. Bioslurry 10 ton $/ \mathrm{ha}+$ Urea $100 \mathrm{~kg} / \mathrm{ha}$ & $13,05^{\mathrm{cd}}$ & $17,2^{\text {cd }}$ \\
\hline $\mathrm{P}_{5}$. Bioslurry 10 ton $/ \mathrm{ha}$ & $9,35^{\mathrm{d}}$ & $16,6^{\mathrm{d}}$ \\
\hline
\end{tabular}

Keterangan : superskrip berbeda pada kolom yang sama menunjukkan perbedaan nyata $(\mathrm{P}<0,05)$

perlakuan pemupukan kombinasi bio-slurry dengan urea terhadap produksi tanaman kedelai tercantum pada Tabel 2.

Berdasarkan hasil uji DMRT menunjukkan bahwa perlakuan bio-slurry 10 ton/ha + urea 25 $\mathrm{kg} / \mathrm{ha}$ (P1) menghasilkan bahan kering tanaman 22,3 g nyata lebih tinggi $(\mathrm{P}<0,05)$ dibanding rendah $(\mathrm{P}<0,05)$ dibanding perlakuan lainnya.

Perlakuan bio-slurry dengan urea $25 \mathrm{~kg} / \mathrm{ha}$ mampu menghasilkan bobot 100 biji nyata lebih tinggi dibanding lainnya. Pemupukan berimbang sesuai dengan kebutuhan tanaman akan menghasilkan produksi tanaman yang optimal. Pemupukan $\mathrm{N}$ berlebih akan menyebabkan 
penundaan pembungaan dan pembentukan buah (Munawar, 2011). Pemberian dosis urea yang rendah pada tanaman kedelai dapat menghasilkan produksi yang tinggi karena tanaman kedelai mampu menambat $\mathrm{N}$ bebas menjadi $\mathrm{N}$ tersedia bagi tanaman sehingga kebutuhan $\mathrm{N}$ terpenuhi secara optimal (Fauzan et al, 2014). Tanaman yang mendapatkan unsur hara $\mathrm{N}$ secara optimal pada fase vegetatif akan menghasilkan fotosintat yang tinggi. Fotosintat yang dihasilkan dari fase vegetatif akan dilanjutkan pada fase generatif dan disimpan dalam bentuk karbohidrat yaitu berupa biji (Zainal et al., 2014). Besarnya fotosintat yang ditranslokasikan ke bagian biji akan berpengaruh pada peningkatan berat biji (Fuady et al., 2012).

\section{Produksi Nitrogen Jerami Kedelai}

Hasil analisis ragam menunjukkan bahwa perlakuan pemupukan kombinasi bio-slurry dengan urea berpengaruh nyata $(\mathrm{P}<0,05)$ terhadap produksi nitrogen $(\mathrm{N})$ jerami kedelai. Hasil uji DMRT perlakuan pemupukan kombinasi bioslurry dengan urea terhadap produksi nitrogen dan fosfor jerami kedelai tercantum pada Tabel 3 .
$(\mathrm{P}<0,05)$ dibanding perlakuan lainnya tetapi tidak berbeda nyata terhadap perlakuan Bioslurry 10 ton/ha (P5) yaitu 24,95 g/tanaman.

Akar tanaman yang dapat tumbuh dengan baik akan mampu meneyerap unsur hara secara optimal (Marques et al., 2011). Tanaman kedelai mampu menyediakan unsur hara $\mathrm{N}$ bagi pertumbuhannya dengan cara menambat $\mathrm{N}$ bebas yang ada di udara (Fauzan et al, 2014). Keberadaan bintil akar berpengaruh pada penambatan nitrogen, semakin tinggi jumlah bintil akar maka akan semakin tinggi pula nitrogen yang ditambat oleh bakteri Rhizobium (Siregar, 2015). Pemberian pupuk $\mathrm{N}$ pada awal pertumbuhan dalam jumlah yang cukup dapat merangsang pertumbuhan bintil akar lebih cepat dan pemberian $\mathrm{N}$ yang tinggi dapat menekan aktivitas rhizobium (Suryati et al., 2009). Kadar N tanah yang tinggi akan menyebabkan terhambatnya proses penambatan $\mathrm{N}_{2}$ oleh bakteri Rhizobium, sehingga kadar $\mathrm{N}$ pada tanaman akan menurun (Mulyadi, 2012). Sehingga semakin tinggi kadar $\mathrm{N}$ yang diberikan pada tanaman kedelai akan menurunkan produksi nitrogen jerami kedelai.

Tabel 3. Rerata Produksi Nitrogen Jerami Kedelai pada Kombinasi Pemupukan Bio-slurry dengan Urea.

\begin{tabular}{lc}
\hline \multicolumn{1}{c}{ Perlakuan } & Produksi Nitrogen Jerami \\
\hline & $\ldots . . \mathrm{g} /$ tanaman.... \\
$\mathrm{P}_{0}$. Tanpa Pupuk (kontrol) $0 \mathrm{~kg} / \mathrm{ha}$ & $21,02^{\mathrm{e}}$ \\
$\mathrm{P}_{1}$. Bioslurry 10 ton $/ \mathrm{ha}+$ Urea $25 \mathrm{~kg} / \mathrm{ha}$ & $62,88^{\mathrm{a}}$ \\
$\mathrm{P}_{2}$ Bioslurry 10 ton $/ \mathrm{ha}+$ Urea $50 \mathrm{~kg} / \mathrm{ha}$ & $50,63^{\mathrm{ab}}$ \\
$\mathrm{P}_{3}$. Bioslurry $10 \mathrm{ton} / \mathrm{ha}+$ Urea $75 \mathrm{~kg} / \mathrm{ha}$ & $41,86^{\mathrm{bc}}$ \\
$\mathrm{P}_{4}$. Bioslurry 10 ton $/ \mathrm{ha}+$ Urea $100 \mathrm{~kg} / \mathrm{ha}$ & $35,70^{\mathrm{cd}}$ \\
$\mathrm{P}_{5}$ Bioslurry 10 ton $/ \mathrm{ha}$ & $24,95^{\mathrm{de}}$ \\
\hline
\end{tabular}

Keterangan : superskrip berbeda pada kolom yang sama menunjukkan perbedaan nyata $(\mathrm{P}<0,05)$

Berdasarkan hasil uji DMRT menunjukkan bahwa perlakuan bio-slurry 10 ton/ha + urea 25 $\mathrm{kg} / \mathrm{ha}(\mathrm{P} 1)$ menghasilkan produksi $\mathrm{N}$ jerami 62,88 $\mathrm{g} /$ tanaman nyata lebih tinggi $(\mathrm{P}<0,05)$ dibanding perlakuan lainnya tetapi tidak berbeda nyata terhadap perlakuan bio-slurry 10 ton/ha + urea 50 $\mathrm{kg} / \mathrm{ha}(\mathrm{P} 2)$ yaitu 50,63 g/tanaman. Perlakuan tanpa pupuk (kontrol) $0 \quad \mathrm{~kg} / \mathrm{ha}$ (P0) menghasilkan produksi $\mathrm{N}$ jerami 21,02 nyata lebih rendah

\section{KESIMPULAN}

Berdasarkan penelitian yang telah dilakukan dapat disimpulkan bahwa perlakuan bio-slurry + urea $50 \mathrm{~kg} / \mathrm{ha}$ mampu meningkatkan tinggi tanaman dan jumlah daun kedelai lebih tinggi dibanding perlakuan yang lain. Perlakuan bioslurry + urea $25 \mathrm{~kg} / \mathrm{ha}$ mampu meningkatkan bahan kering tanaman, bobot 100 biji, produksi $\mathrm{N}$ 
jerami kedelai lebih tinggi dibanding perlakuan lain.

\section{DAFTAR PUSTAKA}

BPS. 2016. Produksi Kedelai Menurut Provinsi (ton) tahun 1993-2015. Berita Resmi Statistik.

Elizabeth, M., Sudiarso, dan B. Guritno. 2014. Komposisi penggunaan kompos limbah penyulingan nilam (LPN) dan pupuk urea pada pertumbuhan dan hasil tanaman kedelai (Glycine Max (L) Merr) var. wilis. J. Produksi Tanaman 1 (6) : 497-500.

Fahmi, A., Syamsudin, S. N. H. Utami, dan B. Radjagukguk. 2010. Pengaruh interaksi hara nitrogen dan fosfor terhadap pertumbuhan tanaman jagung (Zea Mays L) pada tanah regosol dan latosol. Berita Biologi 10 (3) : 297-304.

Fauzan, M. H., Elfarisna, dan Y. Suryati. 2014. Efektivitas pengurangan dosis pupuk urea terhadap pertumbuhan dan produksi kedelai pada beberapa varietas. Fakultas Pertanian. Universitas Muhammadiyah. Jakarta.

Fuady, Z., Mawardi, Melizawati. 2012. Teknik pengendalian gulma dan pengelolaan tanah terhadap petumbuhan dan produksi tanaman kedelai (Glycine $\max$ L. Merril). J. Ilmiah Sains dan Teknologi 12 (3) : 81-87.

Ghulmahdi, M. dan Nuaraeni. 2009. Pengaruh genotipe dan pupuk kandang terhadap pertumbuhan dan produksi kedelai panen muda di lahan kering. Agrovigor 2 (2) : 5458.

Kementerian Pertanian. 2015. Rencana Startegis Kementerian Pertanian Tahun 2015-2019. Kementerian Pertanian Republik Indonesia.

Lingga, P. dan Marsono. 2013. Petunjuk Penggunaan Pupuk. Penebar Swadaya. Jakarta.

Made, U. 2010. Respon berbagai populasi tanaman jagung manis (Zea mays sacharata Sturt.) terhadap pemberian pupuk urea. J. Agroland 17 (2) : 138-143.

Marques, D. D. R., Harjanto, dan T. Supriyadi. 2011. Uji dosis pupuk $\mathrm{P}$ dan $\mathrm{K}$ terhadap pertumbuhan dan hasil tanaman kedelai (Glycine max L. Merril). J. Agrineca 11 (2) : 136-150.

Mukhoyaroh, H. 2015. Pengaruh jenis kedelai, waktu, dan suhu pemeraman terhadap kandungan protein tempe kedelai. Florea. 2 (2) : 47-51.

Mulyadi, A. 2012. Pengaruh pemberian legin, pupuk NPK $(15: 15: 15)$ dan urea pada tanah gambut terhadap kandungan N, P total pucuk dan bintil akar kedelai (Glycine max (L.) Merr.). J. Kaunia 3 (1) : 21-29.

Munawar. A. 2011. Kesuburan Tanah dan Nutrisi Tanaman. IPB Press. Bogor.

Ramalia, H., F, Silvina, dan S. Yoseva. Pengaruh pemberian pupuk cair limbah biogas dan pupuk N, P, K terhadap pertumbuhan dan produksi kedelai edamame (Glycine max (L) Merill). Jom Faperta 2 (1).

Satwiko, T., R. R. Lahay, dan B. S. J. Damanik. 2013. Tanggap pertumbuhan dan produksi beberapa varietas kedelai (Glycine $\max \mathrm{L}$.) terhadap perbandingan komposisi pupuk. Jurnal Online Agroekoteknologi 1 (4).

Siregar, P. 2015. Mekanisme adaptasi akar dan serapan fosfor spesifik tiga genotipe kedelai sebagai respon terhadap kekahatan fosfor pada tanah masam. J. Agritepa 11 (1) : 3143.

Suriadikarta, D. Ardi., dan Simanungkalit, R.D.M. 2006. Pupuk Organik dan Pupuk Hayati. Jawa Barat : Balai Besar Penelitian dan Pengembangan Sumber Daya 1Ahan Pertanaian. Hal 2.

Suryati, D., N. Susanti, dan Hasanudin. 2009. Waktu aplikasu pupuk nitrogen terbaik 
untuk pertumbuhan dan hasil kedelai varietas kipas putih dan galur $13 \mathrm{ED}$. J. Akta Agrosia. 12 (2) : 204-212.

Tim Biogas Rumah. 2013. Pengelolaan dan Pemanfaatan Bio-slurry. Yayasan Rumah Energi, Jakarta.
Zainal, M., A. Nugroho, dan N. E. Suminarti. 2014. Respon pertumbuhan dan hasil tanaman kedelai (Glycine max (L) Merill) pada berbagai tingkat pemupukan $\mathrm{N}$ dan pupuk kandang ayam. J. Produksi Tanaman 2 (6) : 484-490. 